\title{
CELL SURFACE PROPERTIES OF HALOTOLERANT PROBIOTIC LACTOBACILLI
}

\begin{abstract}
Guiomar Melgar-Lalanne, Yadira Rivera-Espinoza, Darío Iker Téllez-Medina and Humberto Hernández-Sánchez*

Depto. de Ingeniería Bioquímica, Escuela Nacional de Ciencias Biológicas - Instituto Politécnico Nacional. Carpio y Plan de Ayala, Col. Sto. Tomás. CP 11340, México, D.F., MEXICO.
\end{abstract}

${ }^{*}$ Corresponding autor: Humberto Hernández Sánchez, hhernan1955@yahoo.com

\begin{abstract}
Cell surface characteristics of two halotolerant commercial probiotics (Lactobacillus casei Shirota and L. plantarum 299v) and three halotolerant potential probiotics (L. plantarum, L. pentosus and L. acidipiscis) isolated from Chiapas cheese were evaluated as well as the presence of exopolysaccharides (EPS) in their cell surface. Results showed no differences between the commercial probiotics and the strains of potential probiotics analyzed. All lactobacilli had similar autoaggregation levels (between 19.22 to $21.08 \%$ ) and were able to coaggregate with gram-positive and gram-negative pathogens. The hydrophobicity to non-polar solvents (xylene, octane and hexadecane) was low. L. casei Shirota and L. plantarum isolated from Chiapas cheese had high affinity to chloroform; furthermore, it was possible to demonstrate the presence of capsular exopolysaccharides (CPS) in these strains because of the presence of carboxyl groups. From the results obtained in this work, it may be concluded that low hydrophobicity affinity to chloroform in these strains is related to the presence of CPS and that the higher affinity to chloroform might be related to CPS in the surface of halotolerant lactobacilli.
\end{abstract}

\section{Indexing terms/Keywords}

Halotolerant lactobacilli; Probiotics, Cell Surface Properties; Hydrophobicity, Exopolysaccharides.

\section{Academic Discipline And Sub-Disciplines}

Biotecnology, Food Microbiology

\section{SUBJECT CLASSIFICATION}

Lactic acid bacteria, probiotics, exopolysaccharides

\section{TYPE (METHOD/APPROACH)}

Research Paper

\section{Council for Innovative Research}

Peer Review Research Publishing System

\section{Journal: JOURNAL OF ADVANCES IN BIOTECHNOLOGY}

Vol. 4 , No. 3

www.cirjbt.org , jbteditor@gmail.com 


\section{INTRODUCTION}

All interactions of microorganisms with their environment are surface phenomena, and therewith involve the properties of the microbial cell surface that determine the microorganism's ability to adhere to a surface [1]. Bacterial cell surface components (adhesins, polysaccharides and proteins) play major roles in the adherence of lactobacilli to the intestinal epithelium, and these interactions might lead to pathogen exclusion and immunemodulation of host cells [2] Microorganisms live attached to biotic or abiotic surfaces by forming polymicrobial aggregates called biofilms, generally composed of more than one specie attached to different surfaces and embedded in extracellular polymeric substances produced by the microorganisms [3]. Inside the human body, cells usually adhere to the epithelial mucosa that covers the oral cavity, the gastrointestinal tract (GIT) and the vagina. A good adhesion to the host is required both for pathogenic and probiotic bacteria.

Probiotics are live microorganisms that confer benefits to the host and ameliorate or prevent some diseases [4, 5]. Actually, most of the commercial probiotics belong to Lactobacillus and Bifidobacterium genera. Lactobacilli contain a great number of species that are able to live in many habitats such as the human gut, vagina and oral cavity [6].

The cell enveope of probiotic bacteria is composed of the lipid bilayer plasma membrane, with embedded proteins, encompassed by the cell wall. The bacterial cell wall consists of a thick multilayered sacculus made of peptidoglycans, along with teichoic acids, exopolysaccharides (EPS), proteinaceous filaments and proteins that are anchored to the cell wall through different mechanisms that are involved in aggregation mechanisms [7, 8]. Some species of lactobacilli display an additional layer of proteins surrounding the peptidoglycan layer called as S-layer [2, 9]. The ability of aggregation may involve the clumping of cells of the same strains (autoaggregation) or different strains (coaggregation). Bacterial probiotic aggregation is related to the ability for both interaction between bacteria close to each other and inhibition of pathogenic adhesion to the intestinal epithelium [10], and it is considered a routine assay for determining the cell adhesion [11]. In the case of probiotic bacteria, autoaggregation provides the release of beneficial substances into the host whilst coaggregation might inhibit or even avoid the adhesion and activity of pathogenic strains. Several studies have been focused on the aggregative properties of potential probiotic microorganisms [12,13,14]. As well, the ability to coaggregate might form a barrier that prevents colonization by other pathogenic bacteria [12]. Finally, the physicochemical properties of the bacterial cell surface might affect their adhesion abilities [15]. Finally, the hydrophobicity of the bacterial cell surface $s$ is related with the presence of some component in the cell surface. For example, high hydrophobicity to chloroform is related with the presence of carboxyl groups [16] that are related with the presence of exopolysaccharides (EPS). EPS quantities and/or qualities are expected to play an important role in colonization and survival within the host [8]. Nonetheless, in the last decades their importance has increased because their prebiotic potential. So, the presence of capsular exopolysaccharides (CPS) might be related to the bacterial survival inside the GIT [17] and some healthy benefits have been recently identified, especially their capacity to reduce blood cholesterol [18].

Research about probiotics into salty food matrices has been increasing during the last years [19]. Resistance to stress in probiotic bacteria will be critical in the survival of probiotics from storage to gastric transit and may perform better their health promoting properties [20]. Recently, the halotolerance ability of two commercial probiotics (Lactobacillus casei Shirota and L. plantarum 299v) was determined [21] along with the probiotic potential of three halotolerant lactobacilli isolated from a Mexican ripened cheese (Lactobacillus plantarum, L. pentosus and L. acidipiscis) [22].

The aim of the present study was to determine the cell surface properties and the presence of EPS in two halotolerant commercial probiotics (Lactobacillus casei Shirota and L. plantarum 299v) and three halotolerant potential probiotics isolated from a tropical Mexican salty cheese (Chiapas cheese) (Lactobacillus plantarum, L. pentosus and L. acidipiscis). For this purpose, the cell surface properties of the five halotolerant lactobacilli were measured as autoaggregation, coaggregation, hydrophobicity and presence of EPS.

\section{MATERIAL AND METHODS}

\section{Bacterial strains and growth conditions}

Two commercial probiotic strains: Lactobacillus casei subs. Shirota (Yakult@) and Lactobacillus plantarum subs. 299v (Protransitus LP®) were used to compare the cell surface properties between probiotic and potential probiotic, halotolerant strains Lactobacillus plantarum, L. pentosus and L. acidipiscis previously isolated, identified and characterized from a tropical salty Mexican cheese [23, 21]. Halotolerance of the five strains was previously confirmed [22]. The five lactobacilli tested were grown in Man Rogosa Sharpe (MRS) broth (Difco, Le Point de Claix, France) at 37으 under aerobic conditions until their use. Pathogen strains of Staphylococcus aureus ATCC 25923, Salmonella enterica Servar. thyphimurium ATCC 14028, Listeria monocytogenes ATCC 19115 and Escherichia coli ATCC 43895 were used for the coaggregation assay and grown in Müeller-Hinton broth (Difco, Le Point de Claix, France) at $37{ }^{\circ} \mathrm{C}$ under aerobic conditions until their use. Additionally, Streptococcus thermophilus ATCC-BAA 250 was employed as a positive control of EPS production and grown in MRS broth at $37^{\circ} \mathrm{C}$. All the strains were preserved frozen at $-20{ }^{\circ} \mathrm{C}$ with glycerol as a cryoprotectant until used.

\section{Aggregation assays}

All Lactobacillus strains were grown statically in MRS broth at $37^{\circ} \mathrm{C}$ for $24 \mathrm{~h}$ under aerobic conditions, harvested by centrifugation (Hettich Universal RF, Tuttlingen, Germany) (3,000 g, 15 min, $4 \stackrel{\circ}{\circ}$ ) washed twice with Phosphate buffer saline (PBS) ( $\mathrm{NaCl} 8 \mathrm{~g} / \mathrm{L} ; \mathrm{KCl} 0.2 \mathrm{~g} / \mathrm{L} ; \mathrm{Na}_{2} \mathrm{HPO}_{4} \cdot 2 \mathrm{H}_{2} 01.44 \mathrm{~g} / \mathrm{L} ; \mathrm{KH}_{2} \mathrm{PO}_{4} 0.24 \mathrm{~g} / \mathrm{L} ; \mathrm{pH} 7.2$ ) and resuspended in the same buffer. Absorbance at $600 \mathrm{~nm}$ was adjusted to $0.28 \pm 0.02$ (Jenway $6405 \mathrm{UV} / \mathrm{Visible}$, London, UK). 
Autoaggreagation ability was determined as previously described [15]. The bacterial suspension were shaken in vortex (Barnestead / Thermoline Maxi-Mis Plus, Dubuque, lowa, USA) during $10 \mathrm{~s}$, incubated at $37^{\circ} \mathrm{C}$ in a water bath (Polyscience Inc, Niles, Illinois, USA) and monitored during different times (0, 2, $4 \mathrm{~h}$ ). Autoaggreagation was determinate as follows:

Autoaggregagion $(A A)=\left[\frac{A_{\text {initial }}-A_{\text {final }}}{A_{\text {initial }}}\right] * 100$ [1]

For coaggregation assay, cell suspensions were prepared as previously described [15]. Equal volumes (4 mL) of each cell suspension (Lactobacillus and pathogens strains) were mixed together in pairs by vortexing for $10 \mathrm{~s}$. Control tubes were set up at the same time, containing $8 \mathrm{~mL}$ of each bacterial suspension on its own. The absorbance $(A)$ at $600 \mathrm{~nm}$ of the suspensions was measured after mixing for $10 \mathrm{~s}$ and at different incubation times $(2$ and $4 \mathrm{~h})$ in a water bath at $37 \stackrel{\circ}{\circ}$. Coaggregation was calculated by using two different equations, the Handley et al. 1987 [24] equation:

Coaggregation $(\%)=\left[1-\frac{A_{\operatorname{mixf}}}{\frac{A_{1}+A_{2}}{2}}\right] * 100$ [2]

And the Malik et al. 2003 [25] equation:

Coaggregation $(\%)=\left[1-\frac{A_{\text {mixi }}}{A_{\text {mixf }}}\right] * 100[3]$

Where $A_{\text {mixt }}$ is absorbance of the mixture at the end time, $A_{\text {mixi }}$ is the absorbance of the mixture at the initial time and $A_{1}$ and $A_{2}$ are the absorbance at the end time of each strain by separate.

\section{Cell surface hydrophobicity}

Cell surface hydrophobicity was determined by the classical Microbial Adhesion to Hydrocarbons (MATH) method developed by [26] modified by [16] with the use of polar solvents. Briefly, all the strains were cultured overnight in MRS broth at $37^{\circ} \mathrm{C}$. After that, cells were harvested by centrifugation $\left(3,000 \mathrm{~g}, 15 \mathrm{~min}, 4{ }^{\circ} \mathrm{C}\right)$, washed twice with phosphateurea-magnesium (PUM) buffer $\left(\mathrm{K}_{2} \mathrm{HPO}_{4} \cdot 3 \mathrm{H}_{2} \mathrm{O} 22.2 \mathrm{~g} / \mathrm{L} ; \mathrm{KH}_{2} \mathrm{PO}_{4}: 7.26 \mathrm{~g} / \mathrm{L} ;\right.$ Urea $\left.1.8 \mathrm{~g} / \mathrm{L} ; \mathrm{MgSO}_{4} 0.2 \mathrm{~g} / \mathrm{L} ; \mathrm{pH} 7.1\right)$ and resuspended in the same buffer to a final absorbance at $560 \mathrm{~nm}$ of $0.48 \pm 0.08$ to standardize the number of bacteria. Non-polar solvents (o-xylene and n-octane) or non-soluble electron acceptor (ethyl acetate) were added to the bacterial suspension in a proportion of 1:4. It is important to comment that in a previous research, with the same five halotolerant lactobacilli, another non-polar solvent was employed with the same strains ( $n$-hexadecane) as well as a non-soluble electron donor (chloroform) [21]. The two-phase system was thoroughly mixed in vortex for 2 min; the aqueous phase was carefully removed after $1 \mathrm{~h}$ of incubation in a water bath at $37^{\circ} \mathrm{C}$ and absorbance at $560 \mathrm{~nm}$ was determined. Hydrophobicity was measured used the following equation:

Hydrophobicity $(H)=\left[\frac{A_{i}-A_{f}}{A_{f}}\right] * 100$ [4]

Where $A_{i}$ is the absorbance at $560 \mathrm{~nm}$ to the aqueous phase at the beginning of the experiment (without the solvent) and $A_{f}$ is the absorbance at $560 \mathrm{~nm}$ of the aqueous phase at the end of the experiment.

\section{Production of EPS}

Congo Red Assay (CRA) was developed as described [27]. Briefly, a Congo red dilution ( $\left.100 \mu \mathrm{g} / \mathrm{mL} \mathrm{H}_{2} 0\right)$ was autoclaved (Tuttnauer 2540E, Brinkmann Instruments, Inc., Westbury, NY, USA) separately and then added to a sterile brain-heart infusion (BHI) supplemented with $36 \mathrm{~g} / \mathrm{L}$ of sucrose. Lactobacilli samples, previously centrifuged (14,000 g, 15 min, 4을 and washed twice with PBS buffer, were inoculated into CRA by the drop technique. Then, plates were incubated under aerobic conditions at $37^{\circ} \mathrm{C}$ for $72 \mathrm{~h}$. The presence of colonies was evaluated at $72 \mathrm{~h}$ based on their color and morphology by following [28] criteria. Streptococcus thermophilus ATCC-BAA 250 was used as a control of non-slime production (intense red colonies).

Ruthenium Red Assay (RRA) was developed by following the methodology proposed by [29]. MRS agar was supplemented with $0.08 \mathrm{~g} / \mathrm{L}$ ruthenium red. Petri dishes were loop seeded and incubated at $37 \stackrel{\circ}{\mathrm{C}}$ for $24 \mathrm{~h}$. EPS-producing colonies were detected by means of the presence of ropy appearance and by touching them with a sterile inoculation loop. Also, the color of the colonies was considered as a factor when ropy colonies appear as white or pink.

\section{Presence of CPS by optical microscopy}

The localization of EPS in the cell wall of the Lactobacillus strains was carried out by optical microscopy using Toluidine blue and Alcian blue as dyes [30]. Briefly, lactobacilli samples were stained with Toluidine blue $(1 \mathrm{~g}$ of Toluidine blue, $2 \mathrm{~g}$ sodium borate, and distilled water to $100 \mathrm{~mL}$ ) or Alcian blue ( $1 \mathrm{~g}$ Alcian blue $8 \mathrm{GX}$ in $100 \mathrm{~mL}$ of $3 \%(\mathrm{v} / \mathrm{v})$ acetic acid). The presence of CPS was observed by phase contrast microscopy (Nikon, Eclipse 50i, Tokyo, Japan).

\section{Statistical analysis}

Results of aggregation and hydrophobicity assays were expressed as the average of three independent experiments done by triplicate in three different days. Each experiment was subjected to one way analysis of variance (ANOVA) followed by 
Student-Newman-Keuls test for comparison of means. The level of significance was $2 \alpha=0.05$. When convenient, Pearson correlation coefficient was determined with the aim of finding possible relationships between variables. All statistical tests were performed by using MS-Exce|® software and Sigma Plot 11.0 (Systat Software Inc., IL, USA).

\section{RESULTS}

\section{Aggregation}

All strains showed low autoaggregation levels (figure 1) and similar behavior at both 2 and $4 \mathrm{~h}(\mathrm{P}>0.05)$. The autoaggregation level was significantly higher $(P \leq 0.05)$ at $4 \mathrm{~h}$ than at $2 \mathrm{~h}$.

Figure 1: Autoaggregation (\%) of Lactobacillus casei Shirota, L. plantarum 299v, L. plantarum, L. pentosus and $L$. acidipiscis at $37^{\circ} \mathrm{C}$ under aerobic and static conditions at 2 and $4 \mathrm{~h}$.

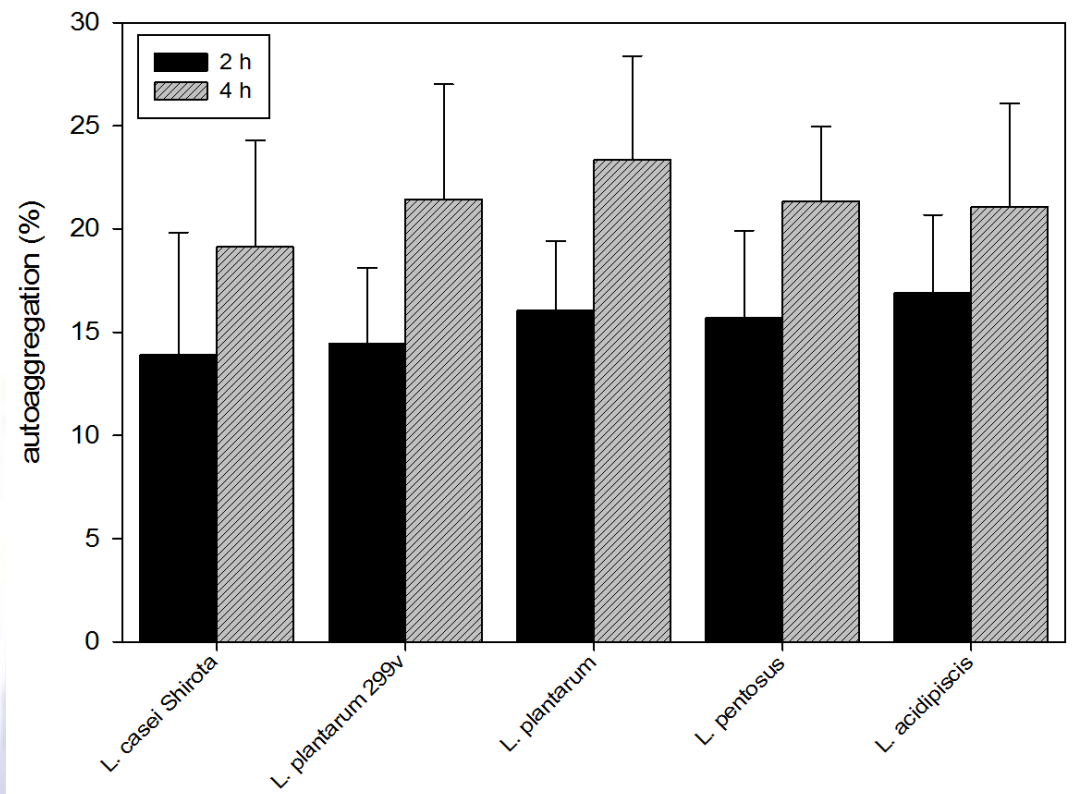

Coaggregation at 2 and $4 \mathrm{~h}$ of each mixture of lactobacilli and pathogens strains were analyzed with equation [2] and equation [3]. Results are shown in table 1.

Coaggregation between halotolerant lactobacilli isolated from Chiapas cheese showed different results using equation [2] and equation [3] (table 2). However, statistically significant differences between these results were not found (P $\geq 0.05)$

Table 1: Coaggregation (\%) of Lactobacillus casei Shirota, L. plantarum 299v, L. plantarum, L. pentosus and $L$. acidipiscis to pathogen strains (Salmonella enterica Serva. Thyphimurium ATCC 14028, Escherichia coli ATCC 4389, Staphylococcus aureus ATCC 25923 and Listeria monocytogenes ATCC 19115) at 2 and 4 h using Handley et al., 1987 equation [2] and equation [3].

\begin{tabular}{|c|c|c|c|c|c|c|}
\hline \multirow{3}{*}{$\begin{array}{l}\text { Co-aggregation } \\
\text { between }\end{array}$} & \multicolumn{3}{|c|}{ [3] } & \multicolumn{3}{|c|}{ [2] } \\
\hline & \multicolumn{2}{|c|}{ Time (h) } & \multirow{2}{*}{$P$} & \multicolumn{2}{|c|}{ Time (h) } & \multirow{2}{*}{$P$} \\
\hline & 2 & 4 & & 2 & 4 & \\
\hline \multicolumn{7}{|l|}{ E. coli ATCC 4389} \\
\hline L. plantarum $299 \mathrm{v}$ & $6.912 \pm 3.062$ & $9.049 \pm 4.716$ & 0.476 & $4.850 \pm 2.507$ & $8.945 \pm 7.795$ & 0.435 \\
\hline L. casei Shirota & $4.536 \pm 2.455$ & $12.642 \pm 3.523$ & 0.003 & $4.722 \pm 0.490$ & $10.386 \pm 0.729$ & $\leq 0.001$ \\
\hline L. plantarum & $5.551 \pm 2810$ & $10.585 \pm 2.948$ & 0.013 & $4.329 \pm 2.601$ & $8.721 \pm 3.811$ & 0.226 \\
\hline L. pentosus & $10.976 \pm 5.387$ & $15.597 \pm 6.651$ & 0.244 & $4.623 \pm 2.968$ & $10.226 \pm 6.421$ & 0.164 \\
\hline L. acidipisciss & $10.124 \pm 6.626$ & $14.996 \pm 8.048$ & 0.279 & $7.451 \pm 3.325$ & $9.899 \pm 2.033$ & 0.338 \\
\hline
\end{tabular}




\begin{tabular}{|c|c|c|c|c|c|c|}
\hline \multirow{3}{*}{$\begin{array}{l}\text { Co-aggregation } \\
\text { between }\end{array}$} & \multicolumn{3}{|c|}{ [3] } & \multicolumn{3}{|c|}{ [2] } \\
\hline & \multicolumn{2}{|c|}{ Time (h) } & \multirow{2}{*}{$P$} & \multicolumn{2}{|c|}{ Time (h) } & \multirow{2}{*}{$P$} \\
\hline & 2 & 4 & & 2 & 4 & \\
\hline \multicolumn{7}{|c|}{ Salmonella 408ntérica servar. Thyphimurium ATCC 14028} \\
\hline L. plantarum $299 \mathrm{v}$ & $11.244 \pm 4.352$ & $13.352 \pm 4.173$ & 0.412 & $8.632 \pm 1.901$ & $11.812 \pm 3.793$ & 0.184 \\
\hline L. casei Shirota & $10.639 \pm 3.594$ & $13.913 \pm 5.222$ & 0.235 & $10.619 \pm 1.426$ & $12.575 \pm 2.927$ & 0.342 \\
\hline L. plantarum & $9.378 \pm 5.595$ & $15.231 \pm 6.418$ & 0.123 & $8.616 \pm 4.702$ & $14.774 \pm 6.996$ & 0.231 \\
\hline L. pentosus & $9.594 \pm 5.047$ & $12.232 \pm 4.960$ & 0.407 & $5.685 \pm 2.134$ & $6.938 \pm 3.448$ & 0.668 \\
\hline L.acidipiscis & $11.007 \pm 3.180$ & $14.740 \pm 3.052$ & 0.159 & $11.335 \pm 5.079$ & $17.660 \pm 2.657$ & 0.054 \\
\hline \multicolumn{7}{|c|}{ S. aureus ATCC 25923} \\
\hline L. plantarum $299 \mathrm{v}$ & $6.671 \pm 1.708$ & $14.173 \pm 4.068$ & 0.002 & $14.826 \pm 7.031$ & $22.037 \pm 7.704$ & 0.255 \\
\hline L. casei Shirota & $7.412 \pm 1.633$ & $15.107 \vee 4.733$ & 0.004 & $10.097 \pm 5.755$ & $19.645 \pm 4.706$ & 0.116 \\
\hline L. plantarum & $7.412 \pm 1.633$ & $11.255 \pm 3.248$ & 0.027 & $13.195 \pm 1.138$ & $17.275 \pm 9.910$ & 0.620 \\
\hline L. pentosus & $9.410 \pm 6.158$ & $14.251 \pm 4.651$ & 0.155 & $18.269 \pm 5.555$ & $11.262 \pm 5.294$ & 0.189 \\
\hline L. acidipiscis & $10.124 \pm 6.624$ & $9.093 \pm 3.485$ & 0.743 & $15.461 \pm 3.657$ & $10.912 \pm 5.253$ & 0.259 \\
\hline \multicolumn{7}{|c|}{ Listeria monocytogenes ATCC 19115} \\
\hline L. plantarum $299 \mathrm{v}$ & $9.746 \pm 5.531$ & $13.487 \pm 4.487$ & 0.227 & $5.496 \pm 1.895$ & $10.767 \pm 3.416$ & 0.036 \\
\hline L. casei Shirota & $18.548 \pm 3.988$ & $11.626 \pm 3.131$ & 0.647 & $12.003 \pm 3.528$ & $12.305 \pm 5.948$ & 0.933 \\
\hline L. plantarum & $10.010 \pm 3.153$ & $12.574 \pm 4.730$ & 0.295 & $12.610 \pm 2.319$ & $15.886 \pm 2.438$ & 0.080 \\
\hline L. pentosus & $8.707 \pm 3.675$ & $13.095 \pm 3.831$ & 0.070 & $10.336 \pm 4.547$ & $14.221 \pm 7.299$ & 0.347 \\
\hline L. acidipiscis & $9.529 \pm 4.187$ & $11.899 \pm 3.171$ & 0.295 & $11.902 \pm 4299$ & $13.850 \pm 2.731$ & 0.459 \\
\hline
\end{tabular}

[2] equation proposed by Handley et al., 1987 y [3] equation proposed by Malik et al., 2003

Table 2: Coaggregation (\%) between (L. casei Shirota, L. plantarum 299v, L. plantarum, L. pentosus and $L$. acidipiscis) at 2 and $4 \mathrm{~h}$ using Handley et al., 1987 equation [2] and equation [3] and One-way ANOVA probability (P).

\begin{tabular}{|c|c|c|c|c|c|c|}
\hline \multirow[t]{3}{*}{$\begin{array}{l}\text { Co-aggregatio } \\
\text { between }\end{array}$} & & [3] & & \multicolumn{2}{|r|}{ [2] } & \multirow{3}{*}{$P$} \\
\hline & \multicolumn{2}{|c|}{ Time $(\mathrm{h})$} & \multirow{2}{*}{$P$} & \multicolumn{2}{|c|}{ Time (h) } & \\
\hline & 2 & 4 & & 2 & 4 & \\
\hline \multicolumn{7}{|l|}{ L. plantarum } \\
\hline L. pentosus & $12.978 \pm 2.808$ & $20.140 \pm 4.711$ & 0.010 & $17.038 \pm 3.212$ & $23.871 \pm 6.348$ & 0.103 \\
\hline L. acidipiscis & $15.781 \pm 2.322$ & $22.354 \pm 3.087$ & 0.002 & $17.333 \pm 5.533$ & $23.469 \pm 4.440$ & 0.061 \\
\hline \multicolumn{7}{|l|}{ L. pentosus } \\
\hline L. acidipiscis & $17.041 \pm 3.401$ & $22.334 \pm 3.541$ & 0.025 & $18.408 \pm 3.768$ & $23.212 \pm 6.749$ & 0.159 \\
\hline \multicolumn{7}{|c|}{ Three halotolerant lactobacilli from Chiapas cheese } \\
\hline & $13.642 \pm 4.809$ & $19.689 \pm 4.612$ & 0.077 & $15.677 \pm 5.820$ & $21.946 \pm 4.830$ & 0.087 \\
\hline
\end{tabular}




\section{Cell surface hydrophobicity (CSH)}

All lactobacilli showed low CSH to the two non-polar solvents (xylene, and octane) (Figure 2). L. acidipiscis had the lowest polar hydrophobicity to chloroform and ethylacetate showing a non-polar character in their surface. However $L$. casei Shirota and showed a strong affinity to the previously reported chloroform showing a basic character the presence of carboxyl groups in their cell surface [16].

Figure 2: Hydrophobicity (\%) at $560 \mathrm{nn}$ to non-polar solvents (xylene, octane and hexadecane) and to polar solvents (chloroform and ethyl acetate) of L. casei Shirota, L: plantarum 299v, L. plantarum, L. pentosus and L. acidipiscis.

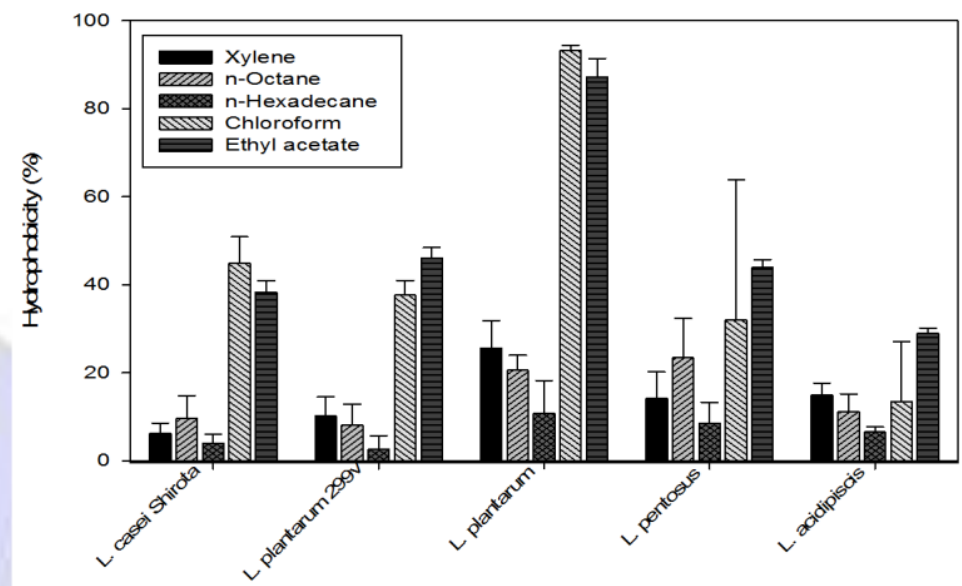

\section{Production of EPS and presence of CPS.}

The production of EPS and the presence of CPS could not be confirmed in the case of L. acidipiscis (table 3 ). L. casei Shirota, L. plantarum 299v and L. plantarum showed both EPS production and presence of CPS and in the case of $L$. pentosus, presence of CPS could not be confirmed.

Table 3: Production of exopolysaccharides (EPS) using Congo Red Agar assay and Ruthenium Red Agar assay and presence of capsular EPS by stain with Toluidine blue and Alcian blue in Lactobacillus casei Shirota, $L$. plantarum 299v, L. plantarum, L. pentosus y L. acidipiscis.

\begin{tabular}{|l|c|c|c|c|}
\hline & \multicolumn{2}{|c|}{ EPS production } & \multicolumn{2}{c|}{ CPS presence } \\
\hline Strain & Congo red agar & $\begin{array}{c}\text { Ruthenium } \\
\text { red agar }\end{array}$ & Toluidine blue & Alcian blue \\
\hline L. casei Shirota & + & + & + & + \\
\hline L. plantarum 299v & + & + & $+/-$ & + \\
\hline L. plantarum & + & + & + & $+/-$ \\
\hline L. pentosus & + & + & - & $+/-$ \\
\hline L. acidipiscis & $+/-$ & $+/-$ & + \\
\hline
\end{tabular}

Where + means presence observed, +/- probably present and - presence not observed

\section{DISCUSSION}

\section{Aggregation}

The aggregation was determined at 2 and $4 \mathrm{~h}$ to simulate the normal gastrointestinal transit time with a low ionic strength buffer (PBS). Thus, this assay takes into account all the strength related with the superficial aggregation and there is not possibility to separate the ionic interactions from van der Waals and Lewis acid-base interactions [31].

Results showed similar autoaggregation levels than previously reported for similar strains under similar conditions [32, 33, $34,35]$. But, no references about autoaggregation of $L$. acidipiscis were found. In some cases, a relationship between salt 
tolerance of the strains, aggregation abilities and EPS production has been found [36]. However, all the halotolerant strains tested had been showed similar salt tolerance [22].

In the case of coaggregation, equation [2] and equation [3], were used to analyze the phenomenon because both equations are almost equally referred in the database Scopus (59 citations equation [2] vs. 57 citations equation [3], as reviewed by April 7, 2014). As found in other research works, the coaggregation index of the lactobacilli was different depending on the equation used [12]. In most cases, coaggregation was similar to previously reported for similar strains $[33,12,37]$. No previous references about $L$. acidipiscis were found. Nevertheless the equation used, in all cases the coaggregation level was low or medium. But, no significant differences $(P>0.05)$ were found between all the mixtures analyzed, despite of the equation employed and the incubation time was not a key factor in most of cases $(P>0.05)$ in spite of the equation used. It is important to indicate that using equation [2] lactobacilli aggregated better with grampositive pathogens than with gram-negative ones.

The determination of aggregation is important in the formation of biofilms to protect the host from colonization by pathogens [33]. In the present research, all the studied strains formed aggregates that may increase adhesion to epithelial cells. However, differences between results obtained by using both equations make it hard to conclude about the coaggregation ability of the lactobacilli studied. Further research work would be necessary in order to deeply analyze the co-aggregation mechanism and to conclude about the use of one equation that could describe properly this phenomenon.

\section{Cell surface hydrophobicity (CSH)}

In a previous research the CSH to n-hexadecane (as non-polar solvent) and chloroform (as electron donor an basic polar solvent) to the same five halotolerant lactobacilli (Lactobacillus casei Shirota, L. plantarum 299v, L. plantarum, L. pentosus and L. acidipiscis) was analyzed [21]. However, in order to achieve a better understanding of the complexity of the bacterial cell surface, it was decided to incorporate two other non-polar solvents (xylene and octane) as well as an acidic polar solvent (ethyl acetate). These two solvents have been incorporated to the present discussion (figure 2).

$\mathrm{CSH}$ to $\mathrm{n}$-hexadecane showed the lowest hydrophobicity to non-polar solvents in the lactobacilli tested. $L$. plantarum, $L$. pentosus and $L$. acidipiscis showed higher hydrophobicity to non-polar solvents than $L$. casei Shirota and $L$. plantarum $299 v$ (figure 2). The results obtained with the three non-polar solvents were independent to each other and no Pearson correlation was found between them (data not shown) in spite the similar physicochemical properties of the three nonpolar solvents analyzed [38] and a great variability in the results were found as in the case of previously reported [39].

Most of the strains showed a high hydrophobicity to both polar solvents and were similar to those previously reported [40, 41]. That suggests a high complexity in the functional groups presents in the cell surface [42, 2]. Moreover, the high affinity to chloroform and the low hydrophobicity to non-polar solvents could be related with the presence of exopolysaccharides in the cell wall $[42,41]$. A chloroform / ethyl acetate rate was calculated and a good correlation between chloroform and ethyl acetate was found $(R=0.961)$ indicating a dependence between them.

Microbial adhesion to non-polar solvents reflects the cell surface hydrophobicity, while the values of adhesion to polar solvents have been regarded as a measure of electron donor or acceptor characteristics of bacteria. Consequently, the surface tension of the solvents, the differences between the results obtained with non-polar and polar solvents indicate the occurrence of Lewis acid-base interactions at the bacterial cell surface [15]. Values obtained with the three non-polar solvents and the two polar solvents might be due to similar van der Waals interactions of solvents [38]. For that reason, the difference observed between the organic solvents analyzed and the lactobacilli tested is probably due to the Lewis acid-base interactions resulting from the electron donor-acceptor characteristics of the different bacterial strains.

By comparing the results from the present research with those from previous researches, many differences in experimental conditions were found such as the use of low ionic strength buffers and the presence or absence of oxygen, the initial microbial concentration, the experimental time and temperature and the solvent concentration used. The kind of buffer used is essential because a low-ionic strength buffer (PBS and $\mathrm{KNO}_{3}$ ) does not eliminate the hydrophobicity produced by ionic strengths and could generate higher hydrophobicity levels than those obtained with highly ionic buffers [43]. Besides, the presence of oxygen may influence the charges in the cell surface, which increases its hydrophilic character [44].

The higher affinity for chloroform is due to a basic or electron-donating faculty of bacterial cells which might be attributed to the presence of carboxylic groups (usually related to the presence of polysaccharides) on the microbial surface [16] and might be related with the presence of capsular EPS in the cell wall. That could explain the fact that the case that in the strain with the lowest chloroform hydrophobicity level the presence of CPS could not be observed.

\section{Production of EPS and presence of CPS}

As previously said, low hydrophobicity values might be related to the presence of EPS in the bacterial cell surface [45]. Moreover, the presence of high hydrophobicity to chloroform could be related with the presence of carboxyl groups in the cell surface that are related with the presence of CPS [16, 46, 47]. So, the low affinity for the chloroform in L. acidipiscis and the lack of Alcian blue and Toluidine staining indicated the short presence of carboxylic groups in their cell wall and so, the absence of CPS. 


\section{CONCLUSIONS}

The evidence presented suggests that two halotolerant lactobacilli potential probiotic (Lactobacillus plantarum, $L$. pentosus) had similar physicochemical characteristics in their cell surface than the halotolerant commercial probiotic $(L$. casei Shirota and L. plantarum 299v). All the strains were able to coaggregate in a similar way to some gram-positive and gram-negative pathogen strains and showed low hydrophobicity to non-polar solvents. The use of both electron donor and electron acceptor polar solvents contributed to the knowledge about the alkalophilic or acidophilic character of the bacterial surface. The high relation between the low hydrophobicity of the five strains studied and the production of EPS for the halotolerant lactobacilli analyzed support the hypothesis that these two properties are related [48]. Moreover, the presence of CPS seems to be related to the low non-polar hydrophobicity and to the basic character of the cell surface (high affinity for chloroform). However, more work is necessary in order to corroborate this hypothesis.

\section{ACKNOWLEDGMENTS}

The National Council for Science and Technology (CONACYT, through the grant 206847) and the National Polytechnic Institute (IPN, through the project SIP-20110353) of Mexico financially supported this research.

\section{CONFLICT OF INTEREST}

The authors declare that they have no conflict of interests.

\section{REFERENCES}

[01]. van der Mei HC, Busscher HJ (2012). Bacterial Cell Surface Heterogeneity: A Pathogen's Disguise. PLoS Pathogens, 8(8), e1002821. http://www.plospathogens.org/article/info\%3Adoi\%2F10.1371\%2Fjournal.ppat.1002821.

[02]. Sengupta R, Altermann E, Anderson RC, McNabb W C, Moughan PJ, Roy NC (2013). The role of cell surface architecture of lactobacilli in host-microbe interactions in the gastrointestinal tract. Mediators of inflammation, 2013, 237921.

[03]. Domínguez-Manzano J, Olmo-Ruiz C, Bautista-Gallego J, Arroyo-López FN, Garrido-Fernández, A, Jiménez-Díaz, R. (2012). Biofilm formation on abiotic and biotic surfaces during Spanish style green table olive fermentation. International Journal of Food Microbiology, 157(2), 230-238.

[04]. Guarner F, Schaafsma G (1998). Probiotics. International Journal of Food Microbiology, 39(3), $237-238$.

[05]. Nagpal R, Behare P, Kumar M, Mohania D., Yadav M., Jain S, Menon S, Parkash O, Marotta F, Minelli E. (2012). Milk, Milk Products, and Disease Free Health: An Updated Overview. Critical Reviews in Food Science and Nutrition, 52(4), 321-333.

[06]. Giraffa G. (2012). Selection and design of lactic acid bacteria probiotic cultures. Engineering in Life Sciences, 12(4), 391-398.

[07]. Wang SY, Chen KN, Lo YM, Chiang, ML, Chen HC, Liu JR., Chen, MJ (2012). Investigation of microorganisms involved in biosynthesis of the Kefir grain. Food Microbiology, 32(2), 274-285.

[08]. Horn N, Wegmann U, Dertli E, Mulholland F, Collins SRA, (2013) Spontaneous Mutation Reveals Influence of Exopolysaccharide on Lactobacillus johnsonii Surface Characteristics. PLoS ONE 8(3): e59957. doi:10.1371/journal.pone.0059957.

[09]. Sánchez B, Ruiz L, Gueimonde M, Ruas-Madiedo P, Margolles A (2012). Toward improving technological and functional properties of probiotics in foods. Trends in Food Science and Technology, 26(1), 56-63.

[10]. Madsen KL (2012). Enhancement of epithelial barrier function by probiotics. Journal of Epithelial Biology and Pharmacology, 5, 55-59.

[11]. Nola S, Erasmus JC, Braga V (2012). Quantitative and Robust Assay to Measure Cell-Cell Contact Assembly and Maintenance. Methods in Molecular Biology (Clifton, NJ), 827, 143.

[12]. Collado MC, Meriluoto J, Salminen S. (2008). Adhesion and aggregation properties of probiotic and pathogen strains. European Food Research and Technology, 226(5), 1065-1073.

[13]. Darilmaz D, Beyatli Y, Yuksekdag, Z. (2012). Aggregation and hydrophobicity properties of 6 dairy propionibacteria strains isolated from homemade Turkish cheeses. Journal of Food Science, 77(1), M20-M24.

[14]. Grześkowiak $Ł$, Collado MC, Salminen S. (2012). Evaluation of aggregation abilities between commensal fish bacteria and pathogens. Aquaculture, 356-357(0), 412-414.

[15]. Kos B, Šušković J, Vuković S, Šimpraga M, Frece J, Matošić S. (2003). Adhesion and aggregation ability of probiotic strain Lactobacillus acidophilus M92. Journal of Applied Microbiology, 94(6), 981-987.

[16]. Bellon-Fontaine MN, Rault J, Van Oss C. (1996). Microbial adhesion to solvents: a novel method to determine the electron-donor/electron-acceptor or Lewis acid-base properties of microbial cells. Colloids Surfaces B: Biointerfaces, 7(1), 47-53. 
[17]. Mozzi F, Gerbino E, Font de Valdez G, Torino MI (2009). Functionality of exopolysaccharides produced by lactic acid bacteria in an in vitro gastric system. J Appl Microbiol 107(1), 56-64

[18]. Prasanna PHP, Grandison AS, Charalampopoulos D (2014) Bifidobacteria in milk products: An overview of physiological and biochemical properties, exopolysaccharide production, selection criteria of milk products and health benefits. Food Research International, 55, 247-262.

[19]. Rivera-Espinoza Y, Gallardo-Navarro,Y (2010). Non-dairy probiotic products. Food Microbiololgy, 27(1), 1-11.

[20]. Corcoran, B., Stanton, C., Fitzgerald, G., \& Ross, R. (2008). Life under stress: the probiotic stress response and how it may be manipulated. Current Pharmaceutical Design, 14(14), 1382-1399.

[21]. Melgar-Lalanne G, Rivera-Espinoza Y, Reyes Méndez Al, Hernández-Sánchez H. (2013). In Vitro Evaluation of the Probiotic Potential of Halotolerant Lactobacilli Isolated from a Ripened Tropical Mexican Cheese. Probiotics and Antimicrobial Proteins, 5(4), 239-251.

[22]. Melgar-Lalanne G., Rivera-Espinoza Y, Farrera-Rebollo R, Hernandez-Sanchez H. (2014). Survival under stress of halotolerant lactobacilli with probiotic properties. Revista Mexicana de Ingeniería Química, 13 (1), $323-335$.

[23]. Morales F, Morales J, Hernández C, Hernández-Sánchez H. (2011). Isolation and Partial Characterization of Halotolerant Lactic Acid Bacteria from Two Mexican Cheeses. Applied Biochemistry and Biotechnology, 164(6), 889905.

[24]. Handley PS, Harty DWS, Wyatt JE, Brown CR, Doran JP, Gibbs ACC (1987). A comparison of the adhesion, coaggregation and cell-surface hydrophobicity properties of fibrillar and fimbriate strains of Streptococcus salivarius. Journal of General Microbiology, 133(11), 3207-3217.

[25]. Malik A, Sakamoto M, Hanazaki S, Osawa M, Suzuki T, Tochigi M, Kakii K (2003). Coaggregation among nonflocculating bacteria isolated from activated sludge. Applied and Environmental Microbiology, 69(10), 6056-6063.

[26]. Rosenberg M, Gutnick D, Rosenberg E (1980). Adherence of bacteria to hydrocarbons: a simple method for measuring cell-surface hydrophobicity. FEMS Microbiology Letters, 9(1), 29-33.

[27]. Ambalam, P., Kondepudi, K.K., Nilsson, I., Wadstr€ om, T. and Ljungh, A. (2012). Bile stimulates cell surface hydrophobicity, Congo red binding and biofilm formation of Lactobacillus strains. FEMS Microbiology Letters, 333,10-19.

[27]. Rosenberg M. (2006). Microbial adhesion to hydrocarbons: twenty-five years of doing MATH. FEMS Microbiology Letters, 262(2), 129-134.

[28]. Arciola CR, Campoccia D, Gamberini S, Cervellati M, Donati E, Montanaro L. (2002). Detection of slime production by means of an optimised Congo red agar plate test based on a colorimetric scale in Staphylococcus epidermidis clinical isolates genotyped for ica locus. Biomaterials, 23(21), 4233-4239.

[29]. Hongpattarakere T, Cherntong N, Wichienchot S, Kolida S, Rastall RA (2012). In vitro prebiotic evaluation of exopolysaccharides produced by marine isolated lactic acid bacteria. Carbohydrate Polymers, 87(1), 846-852.

[30]. Vicente-García V, Ríos-Leal E, Calderón-Domínguez G, Cañizares-Villanueva RO, Olvera-Ramírez, R (2004). Detection, isolation, and characterization of exopolysaccharide produced by a strain of Phormidium 94a isolated from an arid zone of Mexico. Biotechnology and bioengineering,85(3), 306-310.

[31]. Rijnaarts HHM, Norde W, Lyklema J, Zehnder AJB (1999). DLVO and steric contributions to bacterial deposition in media of different ionic strengths. Colloids and Surfaces B: Biointerfaces, 14(1-4), 179-195.

[32]. Kaushik J, Kumar A, Duary R., Mohanty A, Grover S, Batish V (2009). Functional and Probiotic Attributes of an Indigenous Isolate of Lactobacillus plantarum. PLoS ONE, 4(12), e8099.

[33]. Botes M, van Reenen CA, Dicks LMT. (2008). Evaluation of Enterococcus mundtii ST4SA and Lactobacillus plantarum 423 as probiotics by using a gastro-intestinal model with infant milk formulations as substrate. International Journal of Food Microbiology, 128(2), 362-370.

[34]. Ekmekçi H, Aslim B, Darilmaz ÖD (2009). Some factors affecting the autoaggregation ability of vaginal lactobacili isolated from turkish women. Archives of Biological Sciences, $61 \quad(3), 407-412$ http://www.doiserbia.nb.rs/img/doi/0354-4664/2009/0354-46640903407E.pdf

[35]. Bautista-Gallego J, Arroyo-López F, Rantsiou K, Jiménez-Díaz R, Garrido-Fernández A, Cocolin, L. (2012). Screening of lactic acid bacteria isolated from fermented table olives with probiotic potential. Food Research International, 50(1), 135-142.

[36]. Qurashi, AW, Sabri, AN (2012). Bacterial exopolysaccharide and biofilm formation stimulate chickpea growth and soil aggregation under salt stress. Brazilian Journal of Microbiology, 43, 1183-1191.

[37]. García-Cayuela, T., Korany, A. M., Bustos, I., P. Gómez de Cadiñanos, L., Requena, T., Peláez, C., \& MartínezCuesta, M. C. (2014). Adhesion abilities of dairy Lactobacillus plantarum strains showing an aggregation phenotype. Food Research International, 57(0), 44-50. 
[38]. Catalán J(2001) in: G. Wypych (Ed.), Handbook of Solvents: Solvent effects based on pure solvent scales, William Andrew, Inc. and ChemTec Publishing, Toronto -New York, EUA.

[39]. Mishra V, Prasad D. (2005). Application of in vitro methods for selection of Lactobacillus casei strains as potential probiotics. International Journal of Food Microbiology, 103(1), 109-115.

[40]. Nikolic M, Jovcic B, Kojic M, Topisirovic L (2010). Surface properties of Lactobacillus and Leuconostoc isolates from homemade cheeses showing auto-aggregation ability. European Food Research and Technology, 231(6), 925-931.

[41]. Gong X, Yu H, Chen J, Han (2012). Cell surface properties of Lactobacillus salivarius under osmotic stress. European Food Research and Technology 234(4), 671-678.

[42]. Darilmaz D, Beyatli Y. (2012). Investigating Hydrophobicity and the Effect of Exopolysaccharide on Aggregation Properties of Dairy Propionibacteria Isolated from Turkish Homemade Cheeses. Journal of Food Protection, 75(2), 359-365.

[42]. Schär-Zammaretti P, Ubbink J (2003). The cell wall of lactic acid bacteria: surface constituents and macromolecular conformations. Biophysics Journal, 85(6), 4076-4092.

[44]. Boonaert CJ, Rouxhet P G. (2000). Surface of lactic acid bacteria: relationships between chemical composition and physicochemical properties. Applied and Enviornmental Microbioloby, 66(6), 2548-2554. http://aem.highwire.org/content/66/6/2548.full.pdf+html

[45]. Kavita K, Mishra A, Jha B (2013). Extracellular polymeric substances from two biofilm forming Vibrio species: Characterization and applications. Carbohydrate Polymers 94(2), 882-888.

[46]. Bush, CA, Martin-Pastor M, Imbery A. (1999). Structure and conformation of complex carbohydrates of glycoproteins, glycolipids, and bacterial polysaccharides. Annual Reviews of Biophysics and Biomolecular structures, 28(1), 269293.

[47]. Samot J, Lebreton J, Badet C (2011). Adherence capacities of oral lactobacilli for potential probiotic purposes. Anaerobe, 17(2), 69-72.

[48]. Bonet R, Simon-Pujol MD, Congregado F. (1993). Effects of nutrients on exopolysaccharide production and surface properties of Aeromonas salmonicida. Applied and Enviornmental Microbioloby, 59(8), 2437-2441.

\section{Author' biography with Photo}

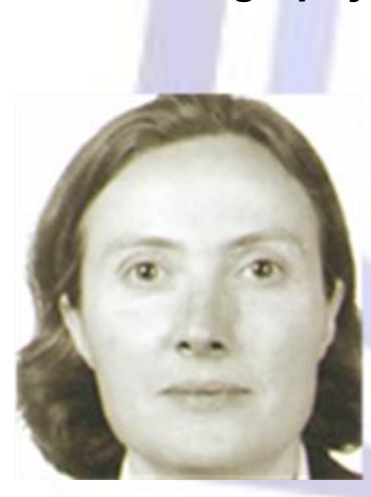

Dr. Melgar-Lalanne completed her Ph .D in Food Science at Nation al Polytechnic In stitute (Mexico City. Mexico). Now, she is a Posdoctoral stu dent at Veracruz University ( Xalapa, Mexico). Her current research interests are on the topics of bacterial adhesion and probiotics. 